\title{
Atrial natriuretic peptide and aldosterone secretions, and atrial natriuretic peptide-binding sites in kidneys and adrenal glands of pregnant and fetal rats in late gestation in response to a high-salt diet
}

\author{
S Deloof, C De Seze, V Montel and A Chatelain \\ Laboratoire de Neuroendocrinologie du Développement (UPRES-EA 2701), Université des Sciences et Technologies de Lille, Bâtiment SN4, \\ F-59655 Villeneuve d'Ascq cedex, France \\ (Correspondence should be addressed to A Chatelain)
}

\begin{abstract}
Objective: This study aimed at determining, in the term pregnant rat, whether maternal and fetal plasma atrial natriuretic peptide (ANP) concentrations were modified in response to an oral sodium load, and to investigate whether any changes in plasma concentrations were able to modify the density and affinity of the different ANP-binding site subtypes in maternal and fetal kidneys and adrenal glands.

Methods: Pregnant rats kept in metabolic cages were divided into two groups. The normal sodium diet group had free access to rat chow and tap water whereas the high sodium diet group received $1 \% \mathrm{NaCl}$ as drinking water for 10 consecutive days from day 11 to day 21 of gestation with free access to standard rat chow. Pregnant rats from both groups were killed by decapitation on day 21 of gestation. The plasma ANP and aldosterone concentrations were determined by RIA. The density and affinity of ANP receptors were determined in the maternal and fetal adrenal glands and kidneys.

Results: In the pregnant rats on the high-salt diet, the sodium and water intakes, as well as the urine volume and sodium excretion, were significantly higher than in the control group. After 10 days of high-salt intake, water and sodium retentions were not significantly different in the two groups, indicating that the pregnant rats were able to excrete excess salt. The high sodium intake did not change the body weight of the pregnant rats but did increase the body weight of the fetal rats. Maternal and fetal hematocrits remained unchanged in both groups, the high sodium intake did not modify plasma sodium concentration in the maternal rats but increased that of the fetuses, indicating an accumulation of sodium in the fetal rats. The dietary sodium intake did not change the plasma ANP concentrations but significantly decreased the plasma aldosterone concentrations in both the maternal and fetal rats. In response to the high-salt diet, the density and affinity of total ANP, ANPb and ANPc receptors were not altered in the maternal isolated renal glomeruli or the adrenal zona glomerulosa membranes or the fetal adrenal gland and kidney membrane preparations.

Conclusion: These results suggest that ANP is not involved in the regulation of water and electrolyte balance in maternal and fetal rats during salt-loaded intake.
\end{abstract}

European Journal of Endocrinology 142 524-532

\section{Introduction}

The regulation of water and sodium balance was studied throughout gestation in both rats placed on a normal diet (1-3) and those on a high-salt diet $(4,5)$. Gravid rats ingesting a high-salt diet present high diuresis and natriuresis $(4,5)$. Atrial natriuretic peptide (ANP) could play an important role in the regulation of water and sodium homeostasis after salt overloading, thanks to its natriuretic, diuretic and aldosteroneinhibiting properties $(6,7)$.

ANP is a cardiac hormone stored in atrial secretory granules (8) which vary in number during alterations of the electrolyte and fluid balance (9). ANP released into the blood circulation in response to atrial distension (10) exerts its biological activity through specific receptors mainly located in the renal glomeruli and adrenal zona glomerulosa (11). In the fetal rat, autoradiographic and binding studies have shown the presence of ANP receptors in the kidney and the adrenal gland $(12,13)$. In order to study the role of ANP in the regulation of sodium homeostasis, adult rats were subjected to chronic salt loading by being given $\mathrm{NaCl}$ solution (14-16) or rat chow containing $\mathrm{NaCl}(17,18)$. The results of these studies were often controversial. Indeed, some investigators have described an increase of 
plasma ANP concentration after salt-loading intake $(14,18,19)$, while others have demonstrated a decrease of plasma concentrations after salt-overloading $(20,21)$ and others have shown that plasma ANP concentrations were not significantly altered by high-sodium intake $(15,16,22,23)$. These discrepancies can be explained by the differences in the protocols used in these experiments. Moreover, most studies showed that the ANP receptors were down-regulated in the adrenal glands and the renal glomeruli in response to saltoverloading $(14,15,19,24,25)$.

The last week of gestation in the rat is marked by an increase in the volume of plasma, accompanied by a retention of sodium in both pregnant rats and their fetuses $(1-3)$. In order to understand these modifications of water-sodium balance observed in late gestation, it is important to study the effects of a high-salt diet on the regulation of plasma ANP concentrations and the density of ANP receptors in pregnant rats and their fetuses in late gestation.

Our aim was to study the effects of a 10-day high-salt diet on water and sodium retention in pregnant rats, maternal and fetal plasma ANP and aldosterone concentrations, and the density and affinity of the different classes of ANP receptors in maternal and fetal kidneys and adrenal glands.

\section{Materials and methods}

\section{Animals}

Experiments were performed on Wistar rats bred in the laboratory. They were housed in a light-controlled room (light period 0700 to $1900 \mathrm{~h}$ ). The females were mated with a male for one night. The following day was taken as day 0 of pregnancy if spermatozoa were found in vaginal smears. The pregnant females were kept in metabolic cages and divided into two groups: normal sodium diet (NSD) and high sodium diet (HSD). In the NSD group, the females had free access to tap water and standard rat chow (Usine d'Alimentation Rationnelle, Villemoisson-sur-Orge, France). In the HSD group, the females received $1 \% \mathrm{NaCl}$ as drinking fluid for 10 consecutive days from day 11 to day 21 of gestation with free access to standard rat chow. All the pregnant females were killed on day 21 of gestation by decapitation and truncal blood was collected between 0800 and $1000 \mathrm{~h}$. Their fetuses were rapidly delivered by Cesarean section, and bled at the trunk level in less than 4 min in order to avoid fetal stress.

Blood samples were collected in chilled plastic tubes containing $5 \%$ EDTA $(20 \mu \mathrm{l}$ for $1 \mathrm{ml}$ blood $)$ and centrifuged at $5000 \mathrm{~g}$ for $10 \mathrm{~min}$ at $4{ }^{\circ} \mathrm{C}$. Aprotinin ( $5 \mathrm{IU}$ for $1 \mathrm{ml}$ plasma) was added only for ANP assay. All the plasma samples were stored at $-80^{\circ} \mathrm{C}$.

Maternal and fetal body weight, maternal fluid and food intake, and the urine volume were measured on day 21 of gestation for a 24-h period. Sodium concentration was determined by flame photometer (Spectr. AA10 Varian, Techtron Pty. Limited, Mulgrave, Victoria, Australia) in plasma and urine samples. Hematocrit was determined by a microcapillary technique (Microcentrifuge, CRITSPIN, Poly Labo, Strasbourg, France).

In the NSD group, the amount of sodium ingested by the pregnant rats was determined by multiplying the amount of food eaten by the sodium content in standard chow $(0.030 \mathrm{mEq} / \mathrm{g})$. In the HSD group, the amount of sodium ingested by the pregnant rats was determined by adding the amount of sodium contained in the food which was eaten and the amount of sodium contained in the volume of the saline solution drunk $(0.17 \mathrm{mEq} /$ $\mathrm{ml})$. The amount of sodium excreted was calculated by multiplying the urine volume by the urinary sodium concentration. The sodium excreted with the feces was not determined and the sodium concentration in tap water was very low $(0.02 \mathrm{mEq} / \mathrm{l})$.

\section{Determination of aldosterone and ANP concentrations in maternal and fetal plasma}

The plasma aldosterone concentrations were measured by RIA after extraction of aldosterone from the plasma with ethyl acetate after delipidation with iso-octane and assayed as previously described (26). Intra- and interassays were respectively $\pm 5.00 \%(n=11)$ and $13.00 \%$ $(n=7)$ and recovery of aldosterone from plasma was over 95\% $(n=10)$. Aldosterone concentration was expressed as nmol/l.

The plasma ANP concentrations were determined using an RIA kit (RIK-9103; Peninsula Laboratories, Belmont, CA, USA) after extraction of ANP from plasma with $\mathrm{C}_{18}$ Sep-Pak cartridges eluted with a buffer containing $60 \%$ acetonitrile in 1\% trifluoroacetic acid. Recovery of ANP from plasma was over $95 \%(n=5)$. Immunoreactive ANP concentration was expressed as pmol/l.

\section{Preparation of tissue samples}

The adrenal glands and kidneys of fetuses and pregnant females were rapidly dissected and defatted. The adrenals of mothers were decapsuled in order to separate the capsule with zona glomerulosa from the inner tissue. All the tissues were frozen in liquid nitrogen and stored at $-80^{\circ} \mathrm{C}$. For each experiment $6-8$ maternal adrenals, 4 maternal kidneys, 180-200 fetal adrenals and 4050 fetal kidneys were pooled to prepare tissue samples for one binding assay.

Fetal adrenals and kidneys with medulla and maternal capsules with zona glomerulosa were ground with a Teflon homogenizer in Tris-HCl buffer $(50 \mathrm{mmol} / \mathrm{l}$, $\mathrm{pH} 7.4)$ containing $\mathrm{MnCl}_{2}$ (5 mmol/l), $\mathrm{NaCl}(120 \mathrm{mmol} /$ $\mathrm{l})$, aprotinin $(1 \mu \mathrm{mol} / \mathrm{l})$ and bacitracin $(0.1 \%)$. Homogenates were centrifuged at $1000 \mathrm{~g}$ for $20 \mathrm{~min}$ at $4^{\circ} \mathrm{C}$ and the supernatants were centrifuged at $20000 \mathrm{~g}$ for $30 \mathrm{~min}$ at $4^{\circ} \mathrm{C}$. The pellets containing the membranes 
were rinsed with Tris- $\mathrm{HCl}$ buffer, centrifuged again at $20000 \mathrm{~g}$ for $30 \mathrm{~min}$ at $4^{\circ} \mathrm{C}$ and then diluted with Tris-HCl buffer. An aliquot was taken for protein determination and the remainder frozen in liquid nitrogen and stored at $-80{ }^{\circ} \mathrm{C}$ until required for the binding assay. The maternal glomeruli were prepared according to the technique previously described by Sraer et al. (27). The kidneys excised from the renal capsule were cut longitudinally in order to remove the inner tissue. The minced cortical tissue was passed successively through a $106 \mu \mathrm{m}$ metal sieve which excluded the tubules and blood vessels and a $53 \mu \mathrm{m}$ metal sieve which retained the glomeruli. The glomerular suspensions were rinsed three times with ice-cold Tris- $\mathrm{HCl}$ buffer and centrifuged at $1000 \mathrm{~g}$ for $5 \mathrm{~min}$ at $4^{\circ} \mathrm{C}$ and then diluted with Tris- $\mathrm{HCl}$ buffer. The purity of the preparation was verified by light microscopy and tubular fragments were always below $2 \%$ of the total number of glomeruli. An aliquot was taken for protein determination and the remainder frozen in liquid nitrogen and stored at $-80^{\circ} \mathrm{C}$ until required for binding. The protein content was determined by the method of Lowry et al. (28) using bovine serum albumin (BSA) as standard.

\section{Binding assay}

The fetal and maternal membrane preparations at a concentration of $100 \mu \mathrm{g}$ per tube were incubated in a final volume of $250 \mu \mathrm{l}$ Tris- $\mathrm{HCl}$ buffer containing $0.5 \% \mathrm{BSA}, 25 \mathrm{pmol} / \mathrm{l}^{125} \mathrm{I}^{-\mathrm{rANP}}(1-28)$ (Amersham International plc, Amersham, Bucks, UK) and unlabeled rANP $_{(1-28)}$ (Peninsula) ranging from $10^{-11}$ to $10^{-8} \mathrm{~mol} / \mathrm{l}$ for the determination of the total population of ANP receptors. The density of $\mathrm{ANPb}$ receptors was assessed with $\mathrm{rANP}_{(1-28)}$ in the presence of an excess of $\operatorname{cANP}_{(4-23)}(0.1 \mu \mathrm{mol} / \mathrm{l}$; Peninsula), a truncated ANP peptide which binds selectively to ANPc receptors. The density of ANPc receptors was obtained by subtracting the number of $\mathrm{ANPb}$ receptors from the total receptor population. The binding studies were performed in duplicate at room temperature for $90 \mathrm{~min}$. At the end of incubation, free ${ }^{125} \mathrm{I}-\mathrm{rANP}{ }_{(1-28)}$ was separated from that bound to membranes, by filtration through $0.1 \%$ polyethylenimine-treated Whatman GF/C filters (Prolabo,
Marcq-en-Barul, France), washed with $0.9 \% \mathrm{NaCl}$ and counted in an LKB gamma counter. The non-specific binding was measured in the presence of an excess of $\operatorname{rANP}_{(1-28)}(0.1 \mu \mathrm{mol} / \mathrm{l})$ and $\operatorname{cANP}_{(4-23)}(0.1 \mu \mathrm{mol} / \mathrm{l})$. The specific binding was determined by subtracting the non-specific binding from the total binding.

\section{Statistical analysis}

The results are presented as means \pm s.E.M. The significance of differences between mean values was estimated by Student's $t$-test. The binding results were analyzed by the EBDA/LIGAND program to determine the affinity $\left(K_{\mathrm{d}}\right)$ and density $\left(\mathrm{B}_{\max }\right)$ of ANP receptors (29).

\section{Results}

\section{Maternal and fetal body weights $(B W)$ in NSD and HSD groups}

In our experiments, we selected pregnant rats with between 10 and 14 fetuses each. The average number of fetuses per pregnant rat in the NSD group and the HSD group was $12.11 \pm 0.70$ and $12.33 \pm 0.60$ respectively $(n=10$ for each group) $(P>0.05)$. The HSD pregnant rats were not significantly heavier $(P>0.05)$ than the NSD pregnant rats $(378.34 \pm 10.49$ vs $359.00 \pm 6.35 \mathrm{~g}$ respectively; $n=10$ for each group). The quantity of food eaten by both groups was not significantly different $(P>0.05) \quad(7.85 \pm 0.50$ vs $7.39 \pm 0.22 \mathrm{~g} / 100 \mathrm{~g} \mathrm{BW}$ respectively; $n=10$ for each group). The fetal BW of the HSD group was significantly higher $(P<0.001)$ than that of the NSD group $(5.01 \pm 0.05 \quad(n=53)$ vs $4.44 \pm 0.44 \mathrm{~g}(n=47)$ respectively $)$.

\section{Water and sodium balance in NSD and HSD pregnant rats}

The water and sodium intakes were significantly higher in the HSD group than in the NSD group $(P<0.001)$ (Table 1). The urinary water and sodium excretions of the HSD group were significantly higher than those of the NSD group $(P<0.001)$ (Table 1$)$. Water and sodium retention values, calculated as the difference between intake and excretion, were not significantly different between the two groups $(P>0.05)$ (Table 1$)$.

Table 1 Water and sodium balance in normal (NSD) and high-salt diet (HSD) pregnant rats in late gestation. Values are means \pm S.E.M.; there were ten experiments for each result.

\begin{tabular}{|c|c|c|c|c|c|c|}
\hline Diet & $\begin{array}{c}\text { Water intake } \\
(\mathrm{ml} / 100 \mathrm{~g} \mathrm{BW} / 24 \mathrm{~h})\end{array}$ & $\begin{array}{c}\text { Urinary water } \\
\text { excretion } \\
(\mathrm{ml} / 100 \mathrm{~g} \mathrm{BW} / 24 \mathrm{~h})\end{array}$ & $\begin{array}{l}\text { Water retention } \\
(\mathrm{ml} / 100 \mathrm{~g} \mathrm{BW} / 24 \mathrm{~h})\end{array}$ & $\begin{array}{c}\text { Sodium intake } \\
(\mathrm{mEq} / 100 \mathrm{~g} \mathrm{BW} / 24 \mathrm{~h})\end{array}$ & $\begin{array}{c}\text { Urinary sodium } \\
\text { excretion } \\
(\mathrm{mEq} / 100 \mathrm{~g} \mathrm{BW} / 24 \mathrm{~h})\end{array}$ & $\begin{array}{l}\text { Sodium retention } \\
(\mathrm{mEq} / 100 \mathrm{~g} \mathrm{BW} / 24 \mathrm{~h})\end{array}$ \\
\hline NSD & $11.00 \pm 0.50$ & $2.00 \pm 0.50$ & $9.00 \pm 0.40$ & $\begin{array}{c}(\text { Food }) \\
0.22 \pm 0.01 \\
\text { (Food + saline) }\end{array}$ & $0.20 \pm 0.03$ & $0.02 \pm 0.01$ \\
\hline HSD & $18.00 \pm 1.50^{* * *}$ & $8.00 \pm 1.30^{* * *}$ & $10.00 \pm 0.85$ & $3.68 \pm 0.20^{\star * *}$ & $3.65 \pm 0.45^{* * *}$ & $0.03 \pm 0.01$ \\
\hline
\end{tabular}

${ }^{* * *} P<0.01$ compared with NSD. 
Table 2 Effects of salt-loading on maternal and fetal hematocrit, plasma sodium, ANP and aldosterone concentrations in late gestation. Values are means \pm S.E.M. with the number of experiments shown in parentheses.

\begin{tabular}{|c|c|c|c|c|}
\hline & \multicolumn{2}{|c|}{ Pregnant rats } & \multicolumn{2}{|c|}{ Fetal rats } \\
\hline & NSD & HSD & NSD & HSD \\
\hline $\begin{array}{l}\text { Hematocrit } \\
\qquad(\%)\end{array}$ & $\begin{array}{c}35.00 \pm 0.80 \\
(10)\end{array}$ & $\begin{array}{c}36.00 \pm 0.30 \\
(10)\end{array}$ & $\begin{array}{l}35.00 \pm 1.00 \\
(9)\end{array}$ & $\begin{array}{c}34.00 \pm 0.80 \\
(10)\end{array}$ \\
\hline $\begin{array}{l}\text { Plasma Na+ } \\
(\mathrm{mEq} / \mathrm{l})\end{array}$ & $\begin{array}{c}155.00 \pm 5.00 \\
(10)\end{array}$ & $\begin{array}{c}154.00 \pm 10.00 \\
(10)\end{array}$ & $\begin{array}{c}118.00 \pm 4.00 \\
(12)\end{array}$ & $\begin{array}{c}139.00 \pm 2.60^{* * *} \\
(12)\end{array}$ \\
\hline $\begin{array}{l}\text { Plasma ANP } \\
(\mathrm{pmol} / \mathrm{l})\end{array}$ & $\begin{array}{c}63.00 \pm 9.00 \\
(10)\end{array}$ & $\begin{array}{c}68.00 \pm 12.00 \\
(10)\end{array}$ & $\begin{array}{c}1499.00 \pm 122.00 \\
(10)\end{array}$ & $\begin{array}{c}1689.00 \pm 163.00 \\
(8)\end{array}$ \\
\hline $\begin{array}{l}\text { Plasma aldosterone } \\
(\mathrm{nmol} / \mathrm{l})\end{array}$ & $\begin{array}{c}4.50 \pm 0.50 \\
(10)\end{array}$ & $\begin{array}{l}2.00 \pm 0.35^{\star *} \\
(10)\end{array}$ & $\begin{array}{l}3.00 \pm 0.20 \\
(14)\end{array}$ & $\begin{array}{c}1.50 \pm 0.10^{* * *} \\
(9)\end{array}$ \\
\hline
\end{tabular}

${ }^{* \star} P<0.01,{ }^{* \star *} P<0.001$ compared with NSD.

\section{Hematocrit, plasma sodium concentration, aldosterone and ANP concentrations in pregnant and fetal rats in late gestation}

Salt-loading for 10 days did not change the maternal and fetal hematocrit values significantly $(P>0.05)$ (Table 2). The plasma sodium concentration was not significantly different between the HSD and NSD pregnant rats $(P>0.05)$ (Table 2$)$. The plasma sodium concentration was significantly higher in the fetal rats from the HSD group $(P<0.01)$ (Table 2$)$. In pregnant and fetal rats, dietary salt-loading did not significantly change the plasma ANP concentrations $(P>0.05)$ (Table 2) but significantly decreased the plasma aldosterone concentrations $(P<0.01$ and $P<0.001$ respectively) (Table 2).

\section{The effects of maternal salt-loading on density $\left(B_{\text {max }}\right)$ and affinity $\left(K_{d}\right)$ of different ANP receptors in the kidneys and adrenal glands of pregnant and fetal rats in late gestation}

The analysis of competition curves obtained from pregnant and fetal rats revealed that salt-loading for 10 consecutive days did not significantly alter the $\mathrm{B}_{\max }$ of total $\mathrm{ANP}, \mathrm{ANPb}$ and $\mathrm{ANPc}$ receptors, either in maternal renal glomeruli and adrenal zona glomerulosa membranes or in fetal kidney and adrenal membrane preparations $(P>0.05)$ (Figs 1 and 2$)$. No significant difference in $K_{\mathrm{d}}$ of total ANP and $\mathrm{ANPb}$ receptors was observed in the maternal renal glomeruli and adrenal zona glomerulosa membranes or in the fetal kidney and adrenal membrane preparations $(P>0.05)$ (Table 3$)$ in response to maternal salt-loading. In the fetal NSD and HSD kidneys, the $K_{\mathrm{d}}$ values of total ANP receptors were three times higher than those in maternal NSD and HSD glomeruli $(P<0.05)$ (Table 3$)$. The $K_{\mathrm{d}}$ values of total ANP receptors were not significantly different in the adrenal glands of fetal and maternal NSD and HSD groups $(P>0.05)$ (Table 3$)$. The $K_{\mathrm{d}}$ values of $\mathrm{ANPb}$ receptors were not significantly different in fetal or maternal kidneys and adrenal glands in the two groups $(P>0.05)($ Table 3).

\section{Discussion}

In the present study, our results showed that after 10 consecutive days of high-salt diet the pregnant rats maintained their weight balance, in spite of an increase in salt intake induced by sodium appetite, since their consumption of food and their body weight were not different from those of control pregnant rats. This observation is in agreement with previous reports $(4,5)$. Our results showed that the salt-loaded pregnant rats are able to excrete the entire sodium intake by increasing their urine flow. Their plasma sodium concentration, similar

Table 3 Effects of high-salt diet on affinity $\left(K_{d}\right)(\mathrm{pmol} / \mathrm{l})$ of total ANP and ANPb receptors in kidneys and adrenal glands of pregant and fetal rats in late gestation. Values are means \pm S.E.M.; there were seven experiments for each result.

\begin{tabular}{|c|c|c|c|c|c|}
\hline & & \multicolumn{2}{|c|}{ Pregnant rats } & \multicolumn{2}{|c|}{ Fetal rats } \\
\hline & & NSD & HSD & NSD & HSD \\
\hline $\begin{array}{l}\text { Kidney } \\
\text { Adrenal gland }\end{array}$ & $\begin{array}{l}\text { Total ANP receptors } \\
\text { ANPb receptors } \\
\text { Total ANP receptors } \\
\text { ANPb receptors }\end{array}$ & $\begin{array}{l}470 \pm 72 \\
530 \pm 47 \\
328 \pm 47 \\
344 \pm 55\end{array}$ & $\begin{array}{l}558 \pm 83 \\
590 \pm 84 \\
339 \pm 69 \\
332 \pm 67\end{array}$ & $\begin{array}{c}1458 \pm 465^{\star} \\
748 \pm 172 \\
389 \pm 96 \\
430 \pm 121\end{array}$ & $\begin{aligned} 1712 & \pm 460 \dagger \\
887 & \pm 209 \\
382 & \pm 49 \\
359 & \pm 35\end{aligned}$ \\
\hline
\end{tabular}

${ }^{\star} P<0.05$ compared with maternal NSD; $\uparrow P<0.05$ compared with maternal HSD. 


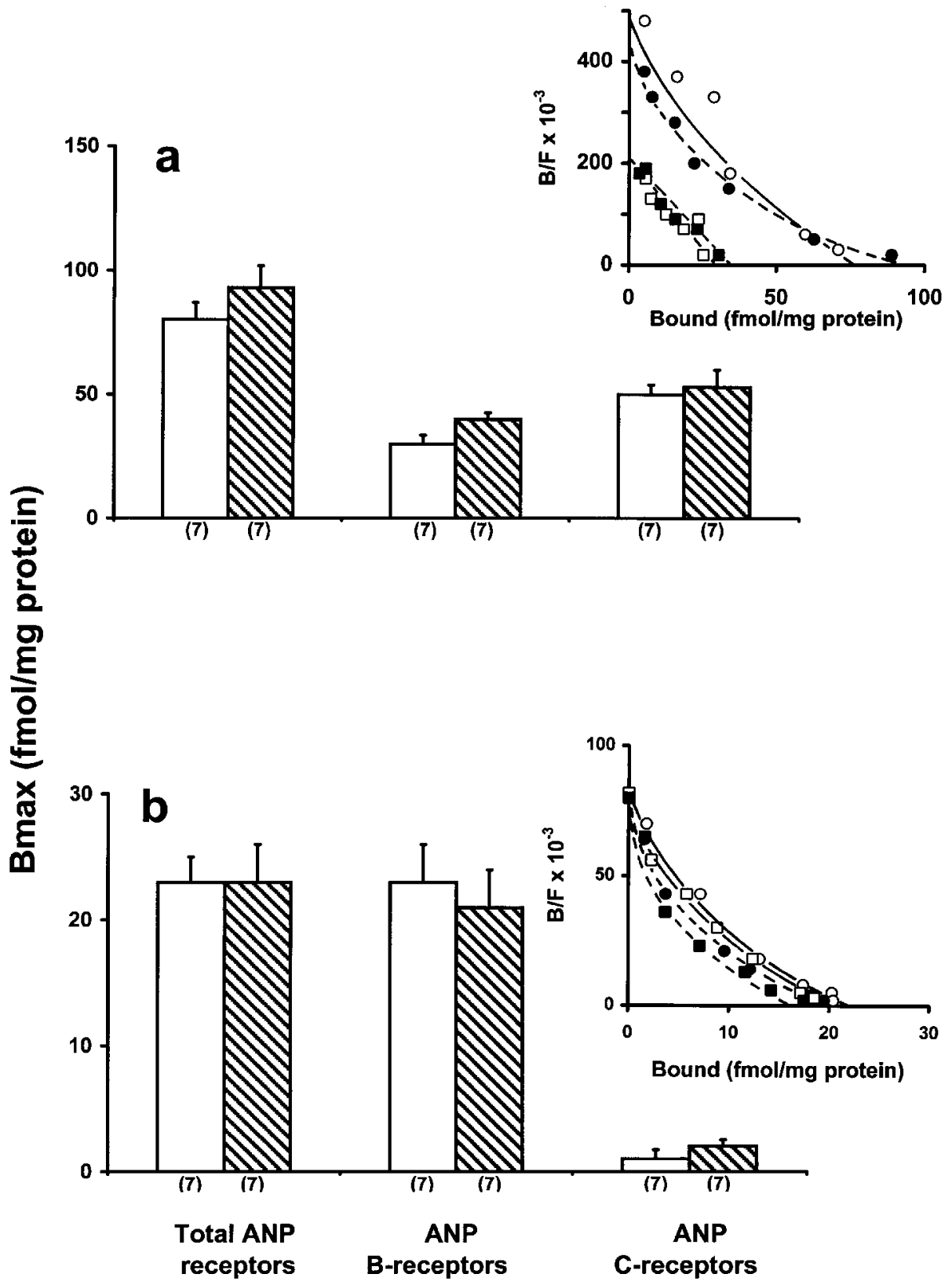

Figure 1 The effect of HSD (10 days) on the density ( $\left.B_{\max }\right)$ of the total ANP, ANPb and ANPc receptors in (a) isolated renal glomeruli and (b) adrenal zona glomerulosa membranes from NSD (open bars) and HSD (hatched bars) maternal rats. Inserts represent one example of Scatchard transformation of binding data; bound/free (B/F) versus bound ANP ( $\mathrm{fmol} / \mathrm{mg}$ protein) in (a) isolated glomeruli and (b) adrenal zona glomerulosa membranes. Curves of total ANP receptors in maternal control $(O)$ and high-salted $(\bullet)$ tissues respectively; curves of ANPb receptors in maternal control $(\square)$ and high-salted ( $\square)$ tissues respectively. Results are means \pm S.E.M.; the number of experiments is given in brackets under the columns.

to that of the control pregnant rats, is additional proof of the complete elimination of excess salt. Several reports have shown that an increase in salt intake leads to an important diuresis and natriuresis in the adult rat (16, $19,20,23,30)$, the pregnant rat $(4,5)$ or an increase in natriuresis in the monkey (31), man (32) and pregnant woman (33).
Our results showed that the high-salt diet of the pregnant rat increased fetal body weight and plasma sodium concentration. The increase in fetal body weight is probably the consequence of an increase in water retention associated with sodium accumulation. Indeed, previous data have shown that the fetal rat is able to retain a great deal of sodium in late gestation (1). 


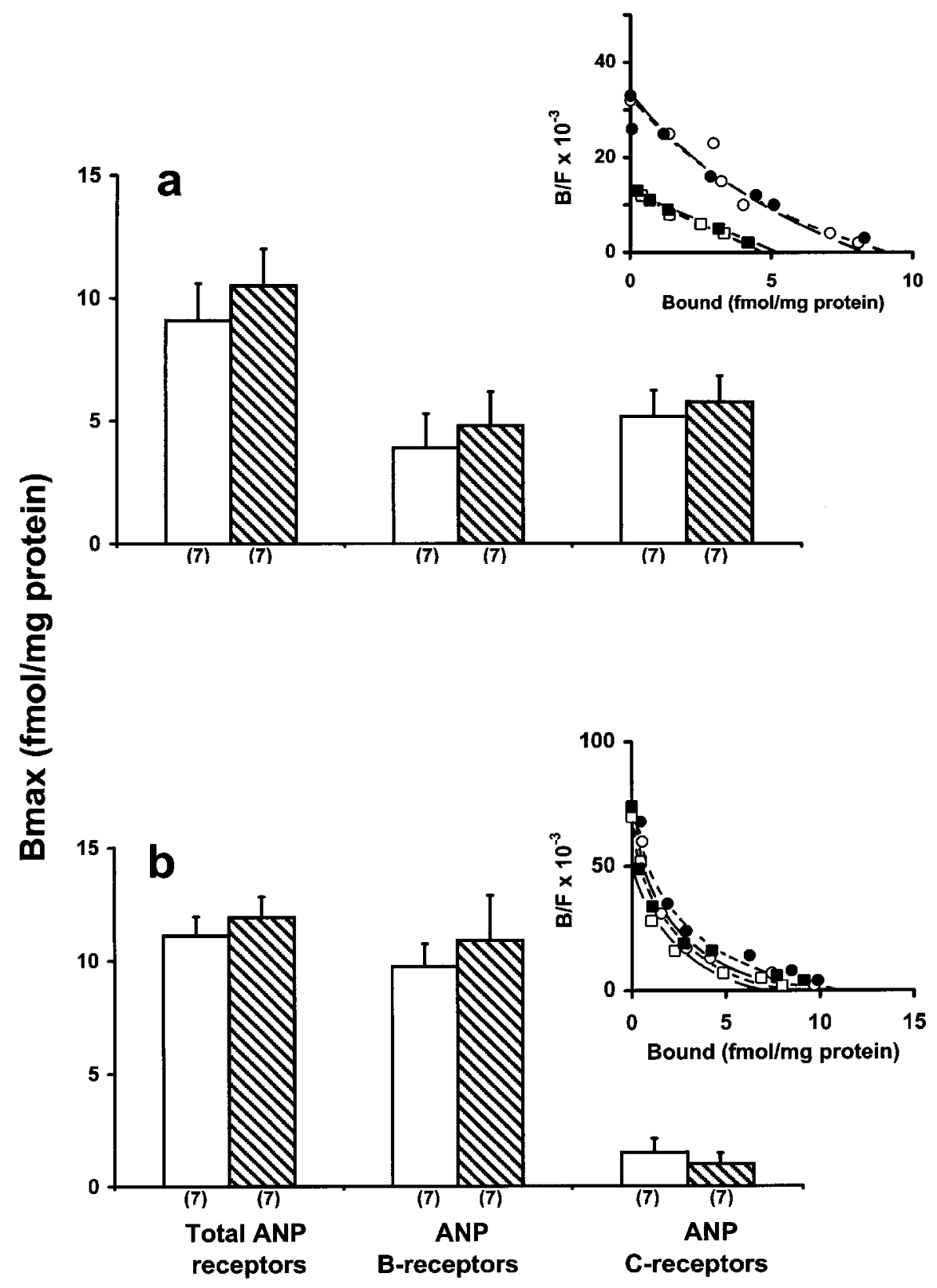

Figure 2 The effect of maternal salt-loading on the density $\left(B_{\max }\right)$ of total ANP, ANPb and ANPc receptors in (a) renal and (b) adrenal membranes from NSD (open bars) and HSD (hatched bars) fetal rats. Inserts represent one example of Scatchard transformation of binding data; bound/free (B/F) versus bound ANP (fmol/mg protein) in (a) renal and (b) adrenal membrane suspensions. Curves of total ANP

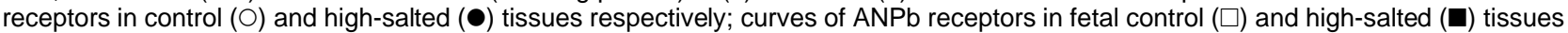
respectively. Results are means \pm S.E.M.; the number of experiments is given in brackets under the columns.

This discrepancy between pregnant and fetal rats is probably due to the immaturity of the fetal kidney which contains only a small number of filtering nephrons (34) and which cannot excrete the amount of sodium.

Several hormonal factors are involved in waterelectrolyte balance. Arginine vasopressin (AVP), the renin-angiotensin-aldosterone system and ANP are among these main factors. Thanks to its natriuretic and diuretic properties, ANP can maintain the water-electrolyte balance by enhancing urinary excretion of sodium and water. Unfortunately, in our study, the plasma ANP levels in the fetal and pregnant rats were not significantly modified by a high-salt diet, suggesting that the amount of salt intake with saline solution does not interfere with ANP secretion. This result is in agreement with those of several investigations which showed that a high-salt diet did not modify the release of ANP in the adult rat $(15,16,22,23)$ or in 
the pregnant rat $(5,35)$. Previous studies have shown that the blood volume expansion is the physiological stimulus of ANP secretion by increasing atrial distension in the adult rat $(36,37)$ and the fetal rat $(38)$. In our study, the unchanged hematocrit values in both pregnant and fetal rats in response to a high-salt diet seem to indicate the absence of extracellular volume increase. The quantity of sodium used in our experiments may be inadequate to produce the increase in plasma volume expansion necessary to produce an atrial distension in both pregnant and fetal salt-loaded rats. From our results, ANP does not seem to be the main hormonal factor which maintains water and electrolyte balance during dietary salt intake. AVP does not seem to participate in this water and sodium homeostasis either, since the plasma AVP concentrations are not changed after a salt-loading treatment during pregnancy in the rat (5). Urodilatin is a peptide that belongs to the family of natriuretic peptides, located in the distal tubular cells and acting as a paracrine hormone within the kidney $(39,40)$. According to Bub et al. (23), urodilatin is stimulated by dietary salt loading and might be involved in the regulation of water and electrolyte balance in the rat. The renin-angiotensin-aldosterone system could play an important role in the regulation of sodium and water homeostasis. Our results show that plasma aldosterone concentrations are significantly reduced by about $50 \%$ in pregnant and fetal rats in response to a high-salt diet. Other studies have reported a significant suppression of the reninangiotensin-aldosterone system after a high-salt diet in the adult rat $(16,30,41-43)$ and pregnant woman (33).

The decrease in fetal plasma aldosterone concentrations in response to a high-salt intake suggests a decrease in the fetal renin-angiotensin system. We did not determine the fetal plasma renin concentrations in our fetal rats but in neonatal rats the renin-angiotensin system is more responsive to chronic sodium loading than that of the adult rat (44).

Previous studies have demonstrated the existence of at least two distinct types of ANP-binding sites in the renal glomeruli and adrenal glomerulosa cells $(45,46)$. One is the biological receptor coupled with guanylate cyclase (ANPb receptor), which is more abundant in the adrenal zona glomerulosa cells than in renal glomeruli, the other, not coupled with guanylate cyclase, is the clearance receptor (ANPc receptor), which is more abundant in renal glomeruli than in adrenal zona glomerulosa and can remove ANP from the blood circulation (47). Both types of ANP receptors are also present in the kidneys and the adrenal glands of the fetal rat at term, in proportions similar to those observed in the adult rat (13).

Our results show that a high-salt intake does not modify the density and affinity of total ANP, ANPb and ANPc receptors in both maternal and fetal kidneys and adrenal glands. These results are in agreement with those of Kollenda et al. (22) who demonstrated that in the renal glomeruli of the adult rat a high-salt diet did not change the density and affinity of total ANP, ANPb and ANPc receptors. However, they disagree with the studies showing a decrease in the number of ANP receptors in adrenal glomerulosa cells (19) and renal glomeruli in the adult rat $(14,48)$.

Our results seem to demonstrate that the total number of ANP-binding sites is less affected by 10 days of salt-loading than by 3 days of dehydration. Indeed, in a recent study, we have shown that water deprivation significantly increased the total number of ANP receptors in renal glomeruli and adrenal zona glomerulosa membranes of the pregnant rat (49). The use of $\mathrm{cANP}_{(4-23)}$ allowed us to demonstrate that the population of ANPc receptors increases in the renal glomeruli and adrenal zona glomerulosa of the pregnant rat, whereas the $\mathrm{ANPb}$ receptor density remains unchanged (49). In contrast, the absence of upregulation of ANP receptors in fetal kidneys and adrenal glands from dehydrated mothers could be associated with the immaturity of those organs (49).

In the fetal kidneys of both groups, the affinity of total ANP receptors is lower than that observed in control and high-salted glomeruli of pregnant rats. This discrepancy could be due to an occupation of ANP receptors in fetal kidneys by endogenous circulating ANP. Indeed, in the fetal rat, the high concentrations of plasma ANP could occupy the small number of ANP receptors compared with the density of ANP receptors in maternal glomeruli; in those conditions, the endogenous peptide still present in fetal renal membrane preparations could compete with the radioligand during the binding studies, thus increasing the apparent $K_{\mathrm{d}}$ in fetal renal preparations.

In our experiments, we did not determine the $K_{\mathrm{d}}$ values of ANPc receptors in maternal and fetal preparations of both groups. The ANPc receptors in fetal kidneys might be mainly occupied with endogenous fetal plasma ANP since the $K_{d}$ values of $\mathrm{ANPb}$ receptors are not significantly different in fetal or maternal preparations of both groups. In isolated renal glomeruli washed with acid in order to reduce the occupation of ANP receptors with endogenous ANP, the affinity of ANPc receptors increased significantly (15).

In conclusion, our findings suggest that pregnant rats are able to maintain water and electrolyte homeostasis and ANP does not seem to be involved in the regulation of water-electrolyte balance during dietary salt intake. Other regulatory mechanisms are involved for maintaining water and sodium homeostasis.

\section{Acknowledgements}

This study was supported partly by a grant from the Conseil Régional du Nord-Pas de Calais (Nord-Pas de Calais Regional Council). The authors wish to thank 
Mrs Yolande Dodey for typing the manuscript and to express their gratitude to Mrs Janet Silverthorn for correcting the English.

\section{References}

1 Churchill SE, Bengele HH \& Alexander EA. Sodium balance during pregnancy in the rat. American Journal of Physiology 1980 239 R143-R148.

2 Atherton JC, Dark JM, Garland HO, Morgan MRA, Pidglon J \& Soni S. Changes in water and electrolyte balance, plasma volume and composition during pregnancy in the rat. Journal of Physiology $198233081-93$

3 Barron WM. Volume homeostasis during pregnancy in the rat. American Journal of Kidney Disease 1987 ix 296-302.

4 Bird E \& Contreras RJ. Dietary salt affects fluid intake and output patterns of pregnant rats. Physiology and Behaviour 198637 365-369.

5 Carvalho EG, Franci CR, Antunes-Rodrigues J, Gutkowska J \& Favaretto ALV. Salt overload does not modify plasma atria natriuretic peptide or vasopressin during pregnancy in rats Experimental Physiology 199883 503-511.

6 Maack T, Atlas SA, Camargo MJ \& Cogan MG. Renal hemodynamic and natriuretic effect of atrial natriuretic factor. Federation Proceedings $1986452188-2132$.

7 Schiebinger RJ, Kem DC \& Brown RD. Effect of atrial natriuretic peptide on ACTH, dibutyryl cAMP, angiotensin II and potassiumstimulated aldosterone secretion by rat adrenal glomerulosa cells. Life Sciences 198842 919-926.

8 Ballerman BJ \& Brenner BM. Biologically active atrial peptides. Journal of Clinical Investigation 198576 2041-2048.

9 De Bold AJ. Heart atria granularity: effects of changes in water electrolyte balance. Proceedings of the Society for Experimental Biology and Medicine 1979161 508-511.

10 Ledsome JR, Wilson N, Courneya CA \& Rankin AJ. Release of atrial natriuretic peptide by atrial distension. Canadian Journal of Physiology and Pharmacology 198563 739-742.

11 Chai SY, Sexton PM, Allen AM, Figdor R \& Mendelsohn FAD. In vitro autoradiographic localization of ANP receptors in rat kidney and adrenal gland. American Journal of Physiology 1986250 F753-F757.

12 Scott JN \& Jennes LH. Ontogeny of atrial natriuretic peptide receptors in fetal rat kidney and adrenal gland. Histochemistry 198991 395-400.

13 Deloof S, De Seze C \& Chatelain A. Identification of two distinct classes of binding sites for atrial natriuretic peptide in the kidney and adrenal gland of the fetal rat at term. Medical Science Research 199624 563-565.

14 Gauquelin G, Garcia R, Carrier F, Cantin M, Gutkowska J, Thibault $\mathrm{G}$ et al. Glomerular ANF receptor regulation during changes in sodium and water metabolism. American Journal of Physiology 1988254 F51-F55.

15 Michel H, Meyer-Lehnert H, Bäcker A, Stelkens H \& Kramer HJ. Regulation of atrial natriuretic peptide receptors in glomeruli during chronic salt loading. Kidney International $19903873-$ 78 .

16 Wolf K \& Kurtz A. Influence of salt intake on atrial natriuretic peptide gene expression in rats. Pflugers Archiv - European Journal of Physiology 1997433 809-816.

17 Schwartz D, Katsube NC \& Needleman P. Atriopeptin release in conditions of altered salt and water balance in the rat. Biochemica and Biophysical Research Communications $1986137922-928$.

18 Penner SB, Thliveris JA, McKenzie JK \& Smyth DD. Atrial-specific granule number and plasma atrial natriuretic peptide in rats: effects of beta-adrenoceptor blockade and sodium intake. Anatomical Record 1990228 418-424.

19 Sessions C, Lawrence D, Clinkingbeard C \& Shenker Y. Regulation of adrenal atrial natriuretic hormone receptor subtypes. Life Sciences $1992501087-1095$.
20 Widimsky J, Kuchel O, Tremblay J \& Hamet P. Distinct plasma atrial natriuretic factor, renin and aldosterone responses to prolonged high-salt intake in hypertensive and normotensive rats. Journal of Hypertension 19919 241-247.

21 Makino Y, Minamino N, Kakishita E, Kangawa K \& Matsuo H. Natriuretic peptides in water-deprived and in salt-loaded rats. Peptides 199617 1031-1039.

22 Kollenda MC, Vollmar AM, McEnroe CA \& Gerbes AL. Dehydration increases the density of $\mathrm{C}$ receptors for ANF on rat glomerular membranes. American Journal of Physiology 1990258 R1084R1088.

23 Bub A, Rechkemmer G, Hock D \& Forssmann WG. Urodilatin secretion in salt-loaded Wistar rats. European Journal of Medical Research $19961417-424$.

24 Lynch DR, Braas KM \& Snyder SH. Atrial natriuretic factor receptors in rat kidney, adrenal gland, and brain: autoradiographic localization and fluid balance dependent changes. Proceedings of the National Academy of Sciences of the USA 1986 83 3357-3361.

25 Schiffrin EL, St-Louis J, Garcia R, Thibault G, Cantin M \& Genest J. Vascular and adrenal binding sites for atrial natriuretic factor. Effects of sodium and hypertension. Hypertension 19868 I-141-I145 .

26 Deloof S, Leprêtre A, Montel V \& Chatelain A. Effect of rat atrial natriuretic factor on in vivo and in vitro aldosterone and corticosterone secretions in the rat during the perinatal period. Biology of the Neonate 199262 145-154.

27 Sraer J, Sraer JD, Chansel D, Russo-Marie F, Kouznetzova B \& Ardaillou R. Prostaglandin synthesis by isolated rat renal glomeruli. Molecular and Cellular Endocrinology 197916 29-37.

28 Lowry OH, Rosebrough NJ, Farr AL \& Randall RJ. Protein measurement with Folin phenol reagent. Journal of Biological Chemistry 1951193 265-275.

29 Munson PJ \& Rodbard D. Ligand: a versatile computerized approach for characterization of ligand-binding systems. Analytical Biochemistry 1980107 220-239.

30 Debinski W, Kuchel O, Buu NT, Nemer M, Tremblay J \& Hamet P. Effect of prolonged high salt diet on atrial natriuretic factor in rats. Proceedings of the Society for Experimental Biology and Medicine $1990194251-257$.

31 Seymour AA, Asaad MM, Abboa-Offei B, Smith PL \& Rogers WL. Sodium loads enhance the natriuretic responses to atrial natriuretic peptide and neutral endopeptidase inhibitors in conscious cynomolgus monkeys. Clinical and Experimental Pharmacology and Physiology 199421 845-856.

32 McKnight JA, Roberts G, Sheridan B \& Atkinson AB. The effect of low and high sodium diets on plasma atrial natriuretic factor, the renin-aldosterone system and blood pressure in subjects with essential hypertension. Clinical Endocrinology 199440 73-77.

33 Lowe SA, Macdonald GJ \& Brown MA. Atrial natriuretic peptide in pregnancy: response to oral sodium supplementation. Clinical and Experimental Pharmacology and Physiology 199219 607-612.

34 Misanko BS, Evan AP, Bengele HH \& Solomon S. Renal response to Ringer expansion in developing rats. Biology of the Neonate 1979 $3552-59$.

35 Castro LC, Arora CP, Davis JL, Hobel CJ \& Parvez H. Atrial natriuretic factor: the effects of pregnancy and a high-salt diet on atrial levels. American Journal of Obstetrics and Gynecology 1989 161 1620-1623.

36 Petterson A, Hedner J, Ricksten SE, Towle AC \& Hedner T. Acute volume expansion as a physiological stimulus for the release of atrial natriuretic peptides in the rat. Life Sciences $1986381127-$ 1133.

37 Khraibi AA, Granger JP, Burnett JC, Walker KR \& Knox PG. Role of atrial natriuretic factor in the natriuresis of acute volume expansion. American Journal of Physiology 1987252 R921-R924.

38 Deloof $\mathrm{S} \&$ Chatelain A. Effect of blood volume expansion on basal plasma atrial natriuretic factor and adrenocorticotropic hormone secretions in the fetal rat at term. Biology of the Neonate 199465 390-395. 
39 Forssmann WG, Nokihara K, Gagelmann M, Hock D, Feller S, Schulz-Knappe $\mathrm{P}$ et al. The heart is the center of a new endocrine, paracrine, and neuroendocrine system. Archives of Histology and Cytology 198952 293-315.

40 Goetz KL. Renal natriuretic peptide (urodilatin?) and atriopeptin: evolving concepts. American Journal of Physiology 1991261 F921-F932.

41 Ingelfinger JR, Pratt RE, Ellison K \& Dzau VJ. Sodium regulation of angiotensinogen mRNA expression in rat kidney cortex and medulla. Journal of Clinical Investigation $1986781311-$ 1315.

42 Nakamura N, Soubier F, Menard J, Panthier JJ, Rougeon F \& Corvol P. Nonproportional changes in plasma renin concentration, renal renin content, and rat renin messenger RNA. Hypertension $19857855-895$.

43 Iwao H, Fukui K, Kim S, Natayama K, Ohkubo H, Nakanishi S et al. Sodium balance effects on renin, angiotensinogen, and atrial natriuretic polypeptide in mRNA levels. American Journal of Physiology 1988255 E129-E136.

44 Jelinek J, Hackenthal E \& Hackenthal R. Role of the reninangiotensin system in the adaptation to high salt intake in immature rats. Journal of Developmental Physiology 199014 8994.
45 Maack T, Suzuki M, Almeida FA, Nussenzveig D, Scarborough RM, McEnroe GA et al. Physiological role of silent receptors of atrial natriuretic factor. Science 1987238 675-678.

46 Mulay S, Omer S, Vaillancourt P, D'Sylva S, Singh A \& Varma DR. Hormonal regulation of atrial natriuretic factor receptors and effects on adrenal glomerulosa cells of female rats. Life Sciences 199455 169-176.

47 Maack T. Receptors of atrial natriuretic factor. Annual Review of Physiology 199259 11-27.

48 Ballerman BJ, Hoover RL, Karnovsky MJ \& Brenner BM. Physiologic regulation of atrial natriuretic peptide receptors in rat renal glomeruli. Journal of Clinical Investigation 198576 2049-2056.

49 Deloof S, De Seze C, Montel V \& Chatelain A. Effects of water deprivation on atrial natriuretic peptide secretion and density of binding sites in adrenal glands and kidneys of maternal and fetal rats in late gestation. European Journal of Endocrinology 1999141 $160-168$.

Received 14 September 1999

Accepted 21 December 1999 